\title{
The Relationship between Transformational Leadership and Organizational Commitment: A Study on the Bank Employees
}

\author{
Ali Çağlar Gulluce ${ }^{*}$, Erdoğan Kaygin ${ }^{2}$, Sultan Bakadur Kafadar², Metin Atay ${ }^{3}$ \\ ${ }^{1}$ Open Education Faculty, Ataturk University, Erzurum, Turkey \\ ${ }^{2}$ Faculty of Economics, Kars Kafkas University, Kars, Turkey \\ ${ }^{3}$ Vocational School of Health Services, Kars Kafkas University, Kars, Turkey \\ Email: "alichaglar@yahoo.com
}

Received 2 June 2016; accepted 21 June 2016; published 24 June 2016

Copyright (C) 2016 by authors and Scientific Research Publishing Inc.

This work is licensed under the Creative Commons Attribution International License (CC BY).

http://creativecommons.org/licenses/by/4.0/

c) (i) Open Access

\begin{abstract}
The purpose of this study is to determine the relationship between transformational leadership and organizational commitment. To this end, a theoretical framework regarding transformational leadership and organizational commitment was created and then an application was performed on bank employees in Kars. The results revealed relations between transformational leadership and organizational commitment. Furthermore, results regarding awareness point out an awareness in continuance commitment, which is one of the sub-dimensions of organizational commitment, in terms of whether management task exists or not.
\end{abstract}

\section{Keywords}

Leadership, Transformational Leadership, Organizational Commitment

\section{Introduction}

Developments and changes emerging in every area in recent years have also spread to leadership area, making way for an increase in the significance of transformational leadership, a type of leadership which focuses on changes.

If leaders take notice of individual development needs of their followers, encourage their followers intellectually, put forward high expectations, provide the acceptance of goals as a whole, behave as a role model, and create a shared vision for future, then they can be said to show transformational behaviors. A leader with trans-

*Corresponding author.

How to cite this paper: Gulluce, A.Ç., Kaygin, E., Bakadur Kafadar, S. and Atay, M. (2016) The Relationship between Transformational Leadership and Organizational Commitment: A Study on the Bank Employees. Journal of Service Science and Management, 9, 263-275. http://dx.doi.org/10.4236/jssm.2016.93033 
formational leadership behaviors aims to transform, encourage and inspire his/her followers for them to perform better than expected [1]. Thus, this way of leadership eases the way of success for corporations and leads to an increase in organizational commitment of employees.

It is no doubt that an employee who works with a good leader will feel more satisfied, leading to an increase in his/her affective commitment to the corporation. Stronger affective commitment will lead to better performance and bring success to corporation, as well. For an employee with high commitment will embrace his/her job and will always do his/her best to go beyond expectations.

This study aims to determine the relationship between the sense of transformational leadership, which has significance for reaching success under tumultuous environmental conditions of our day, and organizational commitment. Within this aim, a study has been conducted on the bank employees working in Kars.

\section{Sense of Transformational Leadership}

The term “transformational leadership”, which emerged for the first time in Mc Gregor's Burns' book "Leadership" in 1978, has been later developed by Bernard Bass et al. as the theory of transformational leadership [2]. Burns has explained the transformational leadership as a leadership style with such properties as charisma among followers and leaders, and a shared vision [3].

Sense of transformational leadership is generally regarded as an effective leadership style. Studies have revealed lots of positive effects of transformational leadership. Sense of transformational leadership indicates a multi-dimensional leadership style, which puts emphasis on common values and needs rather than individual values and needs of followers, and which encourages its followers to perform beyond expectations [4]. Transformational leadership with its focus on change and transformation appeals to emotions of its followers.

Leadership is of much importance when it comes to activating the followers, benefiting from the resources, organizational innovation, adaptation and performance in accordance with the mission of the organization [5]. Khanin (2007) states that transformational leadership can boost the performance of the followers through charisma, intellectual encouragement, individual attention and inspiration [6]. Transformational leadership puts identification with human values to forefront. Transformation leadership requires some certain management values such as righteousness, positive attitudes, sense of responsibility, and commitment. Endeavor for coordination and cooperation between individuals and the team always finds place in the agenda of a transformational leader [7]. Sense of transformational leadership consists of four dimensions [8] [9].

1) Charisma (Idealized Effect): Charisma is the power obtained as a result of the changes in the perceptions and attributions of the followers by the properties and behaviors of the leader, by the situation or conditions of the leadership and by the needs of the followers themselves and this power can activate the followers for the leader [10]. If the person who has this power is a charismatic leader, as indicated also by Koçel, s/he is the one who leads other people according to his/her own will thanks to the charismatic features s/he carries within him/herself; s/he is the one who leads the followers to high performances.

Charismatic leaders bear certain properties such as self-confidence, vision-holding, ability to express his/her own visions to others clearly, having strong beliefs in his/her visions, extraordinary behaviors, being perceived as the one who leads the change, sensibility to the environment [11]. A leader changes the behaviors of his/her followers as a role model for them, helps other leaders create vision for the organization, apply ethical principles, encourage leaders to take risks and also encourages the followers perform efficiently under unstable environmental conditions [12]. A leader evokes admiration in his/her followers and boosts their commitment, thanks to the charisma.

2) Inspiration: Inspiration motivates employees to reach organization's aims successfully and, thus supports leaders in implementing strategies [12]. Inspiration refers to the behaviors of a leader who inspires his/her followers by explaining a challenging mission of the future and activates them [13]. Dimension of inspiration indicates the foundation principles of the organization as a motivation factor rather than the personality of the leader [14].

3) Intellectual Encouragement: Intellectual encouragement abolishes traditional methods for problem solving and activates employees' minds to analyze the business problems comprehensively and solve them [12]. A transformational leader strives to create innovation through intellectual encouragement.

4) Individual Attention: Individual attention emerges when a leader pays attention to individual needs of the followers, when s/he helps them improve their abilities and potentials, and s/he puts importance in their emotions [8]. Transformational leaders establish close relationship with their followers, paying individual attention 
to each of them. Thus, individual needs of the employees are also regarded important. Followers, seeing that their individual needs are paid attention to, will feel that they are important and so they will embrace their jobs more tightly [13]. A transformational leader creates learning opportunities for the followers through individual attention, guides them during the process, sees them as individuals who can make their own decisions, who can analyze and offer solutions for problems, and treats them in accordance with this approach. Individual attention enables the improvement of employees by providing equal opportunities for all employees [14]. Transformational leaders show supportive and formative behaviors when they pay individual attention to their followers [15].

\section{Organizational Commitment}

Organizational commitment is defined as "the strength of an individual's ties with the organization" or "behavioral actions resulting from the commitment of individuals" [16]. Organizational commitment was firstly discussed by Whyte [17] in 1956, and it has been improved by many other researchers such as Porter, in particular, and Mowday, Steers, Allen, Meyer and Becker. Studies conducted since 1956 have revealed the existence of many different notions about commitment.

The most widely accepted definition of organizational commitment is "the relative strength of an individual's ties with to an organization," suggested by Mowday, Steers \& Porter (1979) [18]. Mowday et al. (1979) define the organizational commitment as the identification level of an individual with a certain organization and his/her attention to the organization. O'Reilley and Chatman (1986), on the other hand, explain the organizational commitment as the psychological commitment that an individual feels towards an organization [19].

The most accepted classification regarding the organizational commitment types in literature is the organizational commitment classification developed by Meyer and Allen. They have analyzed this classification as affective commitment, continuance commitment and normative commitment [20]. The three-component model of organizational commitment is explained in Figure 1.

Affective Commitment: It indicates the emotional commitment of an employee to the organization and his/her integration with it. The motivation for an employee to stay in that organization is the emotional commitment and identification of him/her with the goals of the organization. Employees who stay in an organization with strong affective commitment continue to work there not because they need it but because they want it [21].

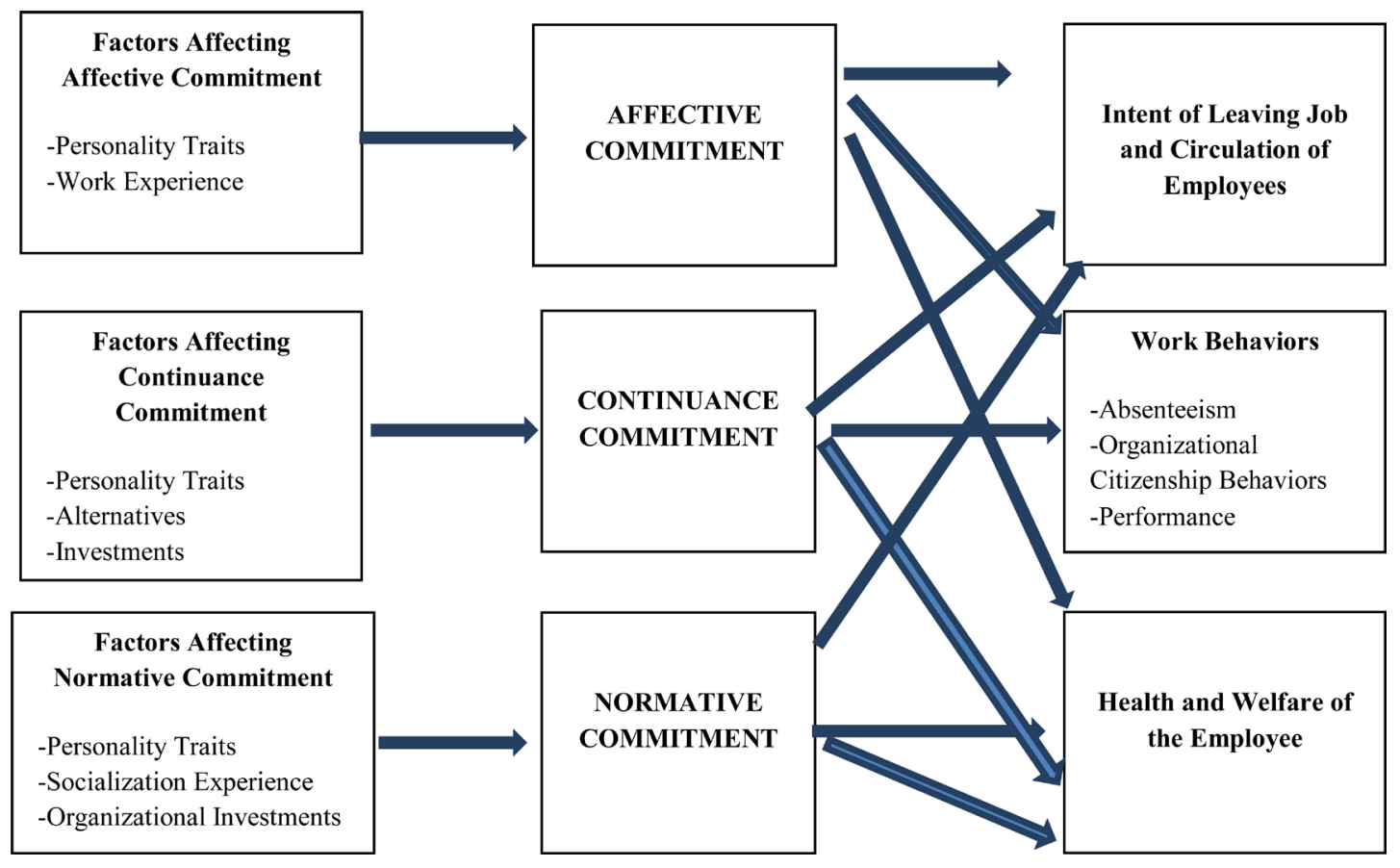

Source: (Meyer et al. 2002: 22)

Figure 1. Three components of organizational commitment. 
The employee regards him/herself as a constituent of the organization and therefore thinks that it is necessary that s/he stays there.

Continuance Commitment: The organizational commitment from a financial aspect brings along the continuance commitment. This type of commitment emphasizes the commitment in proportion to the investment size that an employee has made in the organization. In this sense, continuance commitment points out the awareness of an employee on the costs that s/he will have to bear in case of leaving the job.

Normative Commitment: It highlights the sense of responsibility that an employee feels towards his/her organization to stay there. This type of commitment helps individuals to show some behavioral actions not because they are asked to do so for their personal benefits but because they believe that it is righteous and ethical [21].

\section{The Aim of the Study}

The aim of this study is to determine the relationship between sense of transformational leadership and organizational commitment. The points below are taken as basis in accordance with this main aim:

-To determine the transformational level perception of the employees and their organizational commitment level,

-To determine whether there is a difference in terms of demographical variants between transformational leadership and its sub-components, and organizational commitment and its sub-components among bank employees.

\subsection{The Scope and Method of the Study}

The population of this study consists of approximately 185 bank-employees working in Kars. A 5\% of margin of error within the $95 \%$ of confidence limit from this population was assumed, and the sample size was measured as 125 accordingly [22]. 135 surveys were delivered in total. The number of returning surveys was 130.3 of the surveys were left out of the study due to missing and faulty answers. As a consequence, 127 surveys were evaluated for this study.

Data-acquisition tool for this study is the survey form. The survey consists of three parts. The first part includes questions regarding demographic variants. The second part of the survey has been developed to assess the transformational leadership. The survey has been obtained with the translation of the transformational leadership scale into Turkish which has been developed by Podsakoff in order to measure the transformational leadership and for which factor analysis has been made [23]. This scale contains such components as Providing VisionInspiration and Being a Proper Role Mode in 8 statements, Providing Acceptance of the Group Aims in 5 statements, Encouraging Intellectually in 4 statements, and Having High Expectations of Success in 3 statements. Statements in this part of the scale have been graded between "I do not agree at all" and "I totally agree”. The third part of the survey has been developed by Meyer and Allen in order to assess the organizational commitment. Each component in this scale consists of 8 statements. These components are Affective Commitment, Continuance Commitment and Normative Commitment.

As the reliability of the data is the basic principle of the scientific study and the indicator of the reliability of the data-acquisition tool, the survey has been subjected to reliability test. The results have been evaluated in accordance with the reliability result which has been stated by Özdamar [24].

In Table 1, Cronbach Alpha value of the transformational leadership scale of 23 articles has been found 0.961 in the reliability analysis. This result indicates the high-reliability of this scale.

The results of the reliability analysis applied for the sub-components of transformational leadership scale indicate that Cronbach Alpha values range from 0.648 to 0.920 , and that the components "providing vision-inspiration and being a proper role model”, "providing the acceptance of group aims” "encouraging intellectually” are found to be highly-reliable, whereas "having high expectations for success" and "paying individual attention” are quite-reliable.

In Table 2, Cronbach Alpha value of the organizational commitment scale of 24 articles has been found 0.908 in the reliability analysis. This result indicates the high-reliability of this scale. The results of the reliability analysis applied for the sub-components of the organizational commitment scale indicate that Cronbach Alpha values range from 0.834 to 0.865 , and that components affective commitment, continuance commitment and normative commitments are highly reliable. 
Table 1. Reliability results on transformational leadership and its sub-components.

\begin{tabular}{cccc}
\hline Sub-Components & $\begin{array}{c}\text { Number of } \\
\text { Articles }\end{array}$ & $\begin{array}{c}\text { Cronbach Alpha } \\
\text { Value }\end{array}$ & Reliability Result \\
\hline Transformational Leadership & 23 & 0.961 & Highly Reliable \\
Providing Vision-Inspiration and Being a Proper Role Model & 8 & 0.920 & Highly Reliable \\
Providing Acceptance of Group Aims & 5 & 0.878 & Highly Reliable \\
Encouraging Intellectually & 4 & 0.804 & Highly Reliable \\
Paying Individual Attention & 3 & 0.772 & Quite Reliable \\
Having High Expectations of Success & 3 & 0.648 & Quite Reliable \\
\hline
\end{tabular}

Table 2. Reliability results on organizational commitment and its sub-components.

\begin{tabular}{|c|c|c|c|}
\hline Sub-Components & Number of Articles & Cronbach Alpha & Reliability Result \\
\hline Organizational Commitment & 24 & 0.908 & Highly Reliable \\
\hline Affective Commitment & 8 & 0.837 & Highly Reliable \\
\hline Continuance Commitment & 8 & 0.865 & Highly Reliable \\
\hline Normative Commitment & 8 & 0.834 & Highly Reliable \\
\hline
\end{tabular}

\subsection{Findings}

\subsubsection{Findings on Study Sample}

As can be seen by looking at Table 3, 55.1\% of the participants are men, while $44.9 \%$ are women. While the age range of $5.5 \%$ of the participants is between 18 - 24, 75.6\% of them are between $25-34,17.3 \%$ are between 35 - 44 and $1.6 \%$ are between 45 - 54 . As for marital status, $51.2 \%$ of the participants are married, while $48.8 \%$ are single. As for educational background, $17.3 \%$ of the participants are graduates of high-school/2-year college, while $72.4 \%$ graduated from university, 9.4\% have Master degree and $0.08 \%$ have $\mathrm{PhD}$. As for titles, $9.4 \%$ of the participants are executive officers, $11 \%$ assistant executive officers, $4.7 \%$ supervisors, $2.4 \%$ assistant supervisors, $72.4 \%$ officers. While $39.4 \%$ of participants have worked at the bank for 1 - 5 years, $46.5 \%$ have worked for 6 - 10 years, 13.4\% have worked for 11 - 20 years, and $0.8 \%$ have worked for 21 - 30 years. $12.6 \%$ of employees have management task, while $87.4 \%$ do not have. The rate of those who have wanted to work at bank is $86 \%$, while $13.4 \%$ have not. $70.1 \%$ of participants are satisfied with living in Kars, while $29.9 \%$ are not.

\subsubsection{Findings on Transformational Leadership, Organizational Commitment and Its Sub-Components}

Averages of the answers given by employees for each article are shown in Table 4 and Table 5 to indicate in which level the organization leaders show transformational leadership behaviors and the organizational commitment level of employees. The average values below are regarded as limit for the interpretation of the statements. 1 - 1.79 very low; 1.80 - 2.59 low; 2.60 - 3.39 average; 3.40 - 4.19 high; 4.20 - 5.00 very high.

According to Table 4, While participants' average of transformational leadership scale is $(\bar{x}=3.55)$ and the standard deviation is 0.85 , the average of the sub-component "providing vision-inspiration and being a proper role model" is $(\bar{x}=3.58)$, and the standard deviation is 0.93 . These findings reveal that "transformational leaders create an efficient vision and inspiration for their followers and become a proper role model" $(\bar{x}=3.55>$ 3.40).

The average of the sub-component "providing the acceptance of group aims" is ( $\bar{x}=3.56)$, and the standard deviation is 0.94 . This finding indicates that "transformational leaders can make the employees accept the aim of the groups in a high level” $(\bar{x}=3.56>3.40)$.

The average of sub-component "encouraging intellectually" is $(\bar{x}=3.47)$, and the standard deviation is 0.94 . These findings indicate that "transformational leaders can encourage their followers intellectually in a high level" $(\bar{x}=3.47>3.40)$.

The average of sub-component "paying individual attention" is $(\bar{x}=3.44)$ and the standard deviation is 1.00. These findings indicate that "transformational leaders pay individual attention to their followers in a high level" $(\bar{x}=3.44>3.40)$.

The average of sub-component "having high expectations for success" is $(\bar{x}=3.70)$ and the standard devia- 
tion is 0.80 . These findings indicate that "transformational leaders expect overachievement from the employees in a high level" $(\bar{x}=3.70>3.40)$.

When taken all these findings as a whole, institution leaders generally carry transformational leadership properties in a "high" level and they are perceived to show attitudes and behaviors of transformational leadership.

Table 5 shows that, While participants' average of organizational commitment scale is $(\bar{x}=3.58)$ and the standard deviation is 0.61 , the average of sub-component "affective commitment" is $(\bar{x}=3.60)$ and the standard deviation is 0.61 . These findings indicate that employees have a high level of "affective commitment" $(\bar{x}=$ $3.58>3.40)$.

Table 3. Distribution by demographical data.

\begin{tabular}{|c|c|c|}
\hline & Number of People (N: 127) & Percentage \\
\hline \multicolumn{3}{|l|}{ Gender } \\
\hline Male & 70 & 55.1 \\
\hline Female & 57 & 44.9 \\
\hline Age $18-24$ & 7 & 5.5 \\
\hline Age 25 - 34 & 96 & 75.6 \\
\hline Age $35-44$ & 22 & 17.3 \\
\hline Age 45 - 54 & 2 & 1.6 \\
\hline \multicolumn{3}{|l|}{ Marital Status } \\
\hline Married & 65 & 51.2 \\
\hline Single & 62 & 48.8 \\
\hline \multicolumn{3}{|l|}{ Educational Background } \\
\hline Highschool/2-Year College & 22 & 17.3 \\
\hline University & 92 & 72.4 \\
\hline Master & 12 & 9.4 \\
\hline $\mathrm{PhD}$ & 1 & 0.08 \\
\hline \multicolumn{3}{|l|}{ Title } \\
\hline Executive Officer & 12 & 9.4 \\
\hline Assistant Executive Officer & 14 & 11 \\
\hline Supervisor & 6 & 4.7 \\
\hline Assistant Supervisor & 3 & 2.4 \\
\hline Officer & 92 & 72.4 \\
\hline \multicolumn{3}{|l|}{ Work Experience at Bank } \\
\hline 1 - 5 Years & 50 & 39.4 \\
\hline $6-10$ Years & 59 & 45.5 \\
\hline 11 - 20 Years & 17 & 13.4 \\
\hline 21 - 30 Years & 1 & 0.8 \\
\hline \multicolumn{3}{|l|}{ Management Task } \\
\hline Yes & 16 & 12.6 \\
\hline No & 111 & 87.4 \\
\hline \multicolumn{3}{|l|}{ Chose Willingly to Work at Bank } \\
\hline Yes & 110 & 86.6 \\
\hline No & 17 & 13.4 \\
\hline \multicolumn{3}{|l|}{ Satisfied with Working in Kars } \\
\hline Yes & 89 & 70.1 \\
\hline No & 38 & 29.9 \\
\hline
\end{tabular}


Table 4. Average and standard deviation values on transformational leadership and its subcomponents.

\begin{tabular}{ccc}
\hline Sub-Components & Average & Standard Deviation \\
\hline Transformational Leadership & 3.55 & 0.85 \\
Providing Vision-Inspiration and Being a Proper Role Model & 3.58 & 0.93 \\
Providing the Acceptance of Group Aims & 3.56 & 0.94 \\
Encouraging Intellectually & 3.47 & 0.94 \\
Paying Individual Attention & 3.44 & 1.00 \\
Having High Expectations for Success & 3.70 & 0.80 \\
\hline
\end{tabular}

Table 5. Average and standard deviation values on organizational commitment and its subcomponents.

\begin{tabular}{ccc}
\hline Sub-Components & Average & Standard Deviation \\
\hline Organizational Commitment & 3.58 & 0.61 \\
Affective Commitment & 3.60 & 0.74 \\
Continuance Commitment & 3.54 & 0.75 \\
Normative Commitment & 3.59 & 0.74 \\
\hline
\end{tabular}

Table 6. Relations between transformational leadership, organizational commitment and its sub-components.

\begin{tabular}{|c|c|c|c|c|c|c|c|c|c|c|}
\hline Sub Components & 1 & 2 & 3 & 4 & 5 & 6 & 7 & 8 & 9 & 10 \\
\hline 1.Transformational Leadership & - & & & & & & & & & \\
\hline $\begin{array}{l}\text { 2. Providing Vision-Inspiration and Being a } \\
\text { Proper Role Model }\end{array}$ & $0.980^{* *}$ & - & & & & & & & & \\
\hline 3. Providing the Acceptance of Group Aims & $0.961^{* *}$ & $0.940^{* *}$ & - & & & & & & & \\
\hline 4. Encouraging Intellectually & $0.935^{* *}$ & $0.901^{* *}$ & $0.869^{* *}$ & - & & & & & & \\
\hline 5. Paying Individual Attention & $0.846^{* *}$ & $0.792^{* *}$ & $0.770^{* *}$ & $0.760^{* *}$ & - & & & & & \\
\hline 6. Having High Expectations for Success & $0.731^{* *}$ & $0.667^{* *}$ & $0.657^{* *}$ & $0.628^{* *}$ & $0.510^{* *}$ & - & & & & \\
\hline 7. Organizational Commitment & $0.420^{* *}$ & $0.405^{* *}$ & $0.446^{* *}$ & $0.395^{* *}$ & $0.365^{* *}$ & $0.231^{* *}$ & - & & & \\
\hline 8. Affective Commitment & $0.437^{* *}$ & $0.426^{* *}$ & $0.461^{* *}$ & $0.409^{* *}$ & $0.391^{* *}$ & $0.220^{* *}$ & $0.790^{* *}$ & - & & \\
\hline 9. Continuance Commitment & $0.324^{* *}$ & $0.294^{* *}$ & $0.323^{* *}$ & $0.305^{* *}$ & $0.311^{* *}$ & $0.239^{* *}$ & $0.789^{* *}$ & $0.366^{* *}$ & - & \\
\hline 10. Normative Commitment & $0.268^{* *}$ & $0.272^{* *}$ & $0.308^{* *}$ & $0.253^{* *}$ & 0.192 & $0.105^{* *}$ & $0.870^{* *}$ & $0.570^{* *}$ & $0.563^{* *}$ & - \\
\hline
\end{tabular}

The average of sub-component "continuance commitment" is $(\bar{x}=3.54)$ and the standard deviation is 0.75 . These findings indicate that employees have a high level of continuance commitment $(\bar{x}=3.54>3.40)$.

The average of sub-component normative commitment is $(\bar{x}=3.59)$ and the standard deviation is 0.74 . These findings indicate that employees have a high level of normative commitment $(\bar{x}=3.59>3.40)$.

Affective commitment, a sub-component of organizational commitment, has been found to have the highest average. The lowest average, on the other hand, is the continuance commitment.

\subsubsection{Findings on Correlation Analysis}

In order to analyze the bilateral relations between transformational leadership with its sub-components, and organizational commitment with its sub-components, Pearson correlation analysis has been applied. Findings are presented in Table 6.

There is a positive moderate relationship between transformational leadership scale and organizational commitment scale. There are positive moderate and weak relations between transformational leadership scale and organizational commitment sub-components. The strength of the relations between transformational leadership scale and organizational commitment sub-components ranges from 0.268 to 0.437 . 
There are positive moderate and weak relations between transformational leadership scale sub-components and organizational commitment scale sub-components. The strength of the relations between these sub-components ranges from 0.105 to 0.461 .

\subsubsection{Findings on Differences between Demographical Variants}

In order to determine the differences between demographical variants, independent sample t test and one-way analysis of variance have been applied. Results are presented in Tables 7-10.

According to the result of independent sample t test, there is not any significant difference between females and males in terms of participation level to transformational leadership and its sub-components ( $>0.05)$.

According to the result of independent sample $t$ test, there is not any significant difference between the existence and non-existence of management task in terms of participation level to transformational leadership and its sub-components $(\mathrm{p}>0.05)$.

According to the result of independent sample $t$ test, there is not any significant difference between males and females in terms of participation level to organizational commitment and its sub-components ( $p>0.05)$.

While there is not any significant difference between existence or non-existence of management task for organizational commitment scale and affective commitment and normative commitment sub-components ( $\mathrm{p}>$ 0.05), there is a significant difference for continuance commitment $(\mathrm{p}<0.05)$. Participation level of employees

Table 7. $\mathrm{t}$ test between genders in terms of transformational leadership scale and its sub-components.

\begin{tabular}{|c|c|c|c|c|c|c|}
\hline Sub-Components & Gender & $\mathbf{N}$ & Average & Standard Deviation & $\mathbf{t}$ & $\mathbf{p}$ \\
\hline \multirow{2}{*}{ Transformational Leadership } & Male & 70 & 3.60 & 0.85 & \multirow{2}{*}{0.611} & \multirow{2}{*}{0.543} \\
\hline & Female & 57 & 3.50 & 0.86 & & \\
\hline \multirow{2}{*}{$\begin{array}{l}\text { Providing Vision-Inspiration and Being a } \\
\text { Proper Role Model }\end{array}$} & Male & 70 & 3.63 & 0.90 & \multirow{2}{*}{0.704} & \multirow{2}{*}{0.483} \\
\hline & Female & 57 & 3.52 & 0.97 & & \\
\hline \multirow{2}{*}{ Providing the Acceptance of Group Aims } & Male & 70 & 3.57 & 0.95 & \multirow{2}{*}{0.143} & \multirow{2}{*}{0.886} \\
\hline & Female & 57 & 3.55 & 0.94 & & \\
\hline \multirow{2}{*}{ Encouraging Intellectually } & Male & 70 & 3.50 & 0.94 & \multirow{2}{*}{0.245} & \multirow{2}{*}{0.807} \\
\hline & Female & 57 & 3.45 & 0.94 & & \\
\hline \multirow{2}{*}{ Paying Individual Attention } & Male & 70 & 3.55 & 0.97 & \multirow{2}{*}{1.343} & \multirow{2}{*}{0.182} \\
\hline & Female & 57 & 3.30 & 1.03 & & \\
\hline \multirow{2}{*}{ Having High Expectations for Success } & Male & 70 & 3.73 & 0.83 & \multirow{2}{*}{0.474} & \multirow{2}{*}{0.636} \\
\hline & Female & 57 & 3.67 & 0.77 & & \\
\hline
\end{tabular}

Table 8. $\mathrm{t}$ test on existence of management task in the institutions in terms of transformational leadership scale and its subcomponents.

\begin{tabular}{|c|c|c|c|c|c|c|}
\hline Sub-Components & Management Task & $\mathbf{N}$ & Average & Standard Deviation & $\mathbf{t}$ & $\mathbf{p}$ \\
\hline \multirow{2}{*}{ Transformational Leadership } & Yes & 16 & 3.54 & 0.95 & \multirow{2}{*}{-0.052} & \multirow{2}{*}{0.958} \\
\hline & No & 111 & 3.56 & 0.84 & & \\
\hline \multirow{2}{*}{$\begin{array}{c}\text { Providing Vision-Inspiration and Being a } \\
\text { Proper Role Model }\end{array}$} & Yes & 16 & 3.48 & 0.99 & \multirow{2}{*}{-0.438} & \multirow{2}{*}{0.662} \\
\hline & No & 111 & 3.59 & 0.92 & & \\
\hline \multirow{2}{*}{ Providing the Acceptance of Group Aims } & Yes & 16 & 3.58 & 1.12 & \multirow{2}{*}{-0.065} & \multirow{2}{*}{0.948} \\
\hline & No & 111 & 3.56 & 0.92 & & \\
\hline \multirow{2}{*}{ Encouraging Intellectually } & Yes & 16 & 3.47 & 0.99 & \multirow{2}{*}{-0.026} & \multirow{2}{*}{0.979} \\
\hline & No & 111 & 3.48 & 0.93 & & \\
\hline \multirow{2}{*}{ Paying Individual Attention } & Yes & 16 & 3.50 & 0.97 & \multirow{2}{*}{0.274} & \multirow{2}{*}{0.784} \\
\hline & No & 111 & 3.43 & 1.01 & & \\
\hline \multirow{2}{*}{ Having High Expectations for Success } & Yes & 16 & 3.79 & 0.89 & \multirow{2}{*}{0.500} & \multirow{2}{*}{0.618} \\
\hline & No & 111 & 3.68 & 0.79 & & \\
\hline
\end{tabular}


Table 9. $\mathrm{t}$ test between genders in terms of organizational commitment scale and its sub-components.

\begin{tabular}{|c|c|c|c|c|c|c|}
\hline Sub-Components & Gender & $\mathbf{N}$ & Average & Standard Deviation & $\mathbf{T}$ & $\mathbf{p}$ \\
\hline \multirow{2}{*}{ Organizational Commitment } & Male & 70 & 3.58 & 0.64 & \multirow{2}{*}{-0.019} & \multirow{2}{*}{0.985} \\
\hline & Female & 57 & 3.58 & 0.57 & & \\
\hline \multirow{2}{*}{ Affective Commitment } & Male & 70 & 3.59 & 0.80 & \multirow{2}{*}{-0.232} & \multirow{2}{*}{0.817} \\
\hline & Female & 57 & 3.62 & 0.68 & & \\
\hline \multirow{2}{*}{ Continuance Commitment } & Male & 70 & 3.57 & 0.82 & \multirow{2}{*}{0.393} & \multirow{2}{*}{0.695} \\
\hline & Female & 57 & 3.51 & 0.67 & & \\
\hline \multirow{2}{*}{ Normative Commitment } & Male & 70 & 3.58 & 0.74 & \multirow{2}{*}{-0.210} & \multirow{2}{*}{0.834} \\
\hline & Female & 57 & 3.60 & 0.75 & & \\
\hline
\end{tabular}

Table 10. $t$ test on existence of management task in the institution in terms of organizational commitment scale and its subcomponents.

\begin{tabular}{|c|c|c|c|c|c|c|}
\hline Sub-Components & Management Task & $\mathbf{N}$ & Average & Standard Deviation & $\mathbf{T}$ & $\mathbf{p}$ \\
\hline \multirow{2}{*}{ Organizational Commitment } & Yes & 16 & 3.36 & 0.71 & \multirow{2}{*}{-1.554} & \multirow{2}{*}{0.123} \\
\hline & No & 111 & 3.61 & 0.59 & & \\
\hline \multirow{2}{*}{ Affective Commitment } & Yes & 16 & 3.53 & 1.05 & \multirow{2}{*}{-0.401} & \multirow{2}{*}{0.689} \\
\hline & No & 111 & 3.61 & 0.70 & & \\
\hline \multirow{2}{*}{ Continuance Commitment } & Yes & 16 & 3.17 & 0.98 & \multirow{2}{*}{-2.185} & \multirow{2}{*}{$0.035^{*}$} \\
\hline & No & 111 & 3.60 & 0.70 & & \\
\hline \multirow{2}{*}{ Normative Commitment } & Yes & 16 & 3.37 & 0.68 & \multirow{2}{*}{-1.269} & \multirow{2}{*}{0.207} \\
\hline & No & 111 & 3.62 & 0.75 & & \\
\hline
\end{tabular}

${ }^{*} \mathrm{p}<0.05,{ }^{* *} \mathrm{p}<0.01$.

with a management tasks to "continuance commitment" sub-component is lower than of employees without management task.

\subsubsection{Findings on the Analysis of One-Way Variance (Anova) in Terms of Transformational Leadership and Its Sub-Components}

Data regarding the Anova analysis applied for transformational leadership and its sub-components are presented in Table 11 \& Table 12.

According to the result of the analysis of one-way variance, there is not any significant difference between employees in different age groups in terms of participation level to transformational leadership and its subcomponents $(\mathrm{p}>0.05)$.

According to the result of analysis of one-way variance, there is not any significant difference between employees in different age groups in terms of participation level to transformational leadership and its sub-components $(\mathrm{p}>0.05)$.

\subsubsection{Findings on Analyses of One-Way Variance (Anova) Applied for Organizational Commitment and Its Sub-Components}

Findings with regard to the One-way Anova Analyses can be seen in Table 13 and Table 14.

According to the result of the analysis of one-way variance, there is not any significant difference between employees in different age groups in terms of participation level to organization commitment and its sub-components $(\mathrm{p}>0.05)$.

According to the result of analysis of one-way variance, there is not any significant difference between employees with different educational backgrounds in terms of participation level to organizational commitment and its sub-categories $(\mathrm{p}>0.05)$.

\section{Conclusions}

This study, which has been conducted to determine the relationship between transformational leadership and 
Table 11. Analysis of one-way variance on employees in different age groups in terms of transformational leadership and its sub-components.

\begin{tabular}{|c|c|c|c|c|c|c|}
\hline Sub-Components & Age & $\mathbf{N}$ & Average & Standard Deviation & $\mathbf{F}$ & $\mathbf{p}$ \\
\hline \multirow{5}{*}{ Transformational Leadership } & Between 18 - 24 Years & 7 & 3.48 & 0.88 & \multirow{4}{*}{0.174} & \multirow{4}{*}{0.914} \\
\hline & Between 25 - 34 Years & 96 & 3.54 & 0.86 & & \\
\hline & Between 35 - 44 Years & 22 & 3.60 & 0.86 & & \\
\hline & Between 45 - 54 Years & 2 & 3.93 & 0.09 & & \\
\hline & Between 18 - 24 Years & 7 & 3.54 & 0.95 & \multirow{4}{*}{0.055} & \multirow{4}{*}{0.983} \\
\hline \multirow{4}{*}{$\begin{array}{l}\text { Providing Vision-Inspiration and Being } \\
\text { a Proper Role Model }\end{array}$} & Between 25 - 34 Years & 96 & 3.57 & 0.94 & & \\
\hline & Between 35 - 44 Years & 22 & 3.61 & 0.94 & & \\
\hline & Between 45 - 54 Years & 2 & 3.81 & 0.09 & & \\
\hline & Between 18 - 24 Years & 7 & 3.57 & 0.85 & \multirow{4}{*}{0.578} & \multirow{4}{*}{0.630} \\
\hline \multirow{3}{*}{$\begin{array}{c}\text { Providing the Acceptance of Group } \\
\text { Aims }\end{array}$} & Between 25 - 34 Years & 96 & 3.53 & 0.93 & & \\
\hline & Between 35 - 44 Years & 22 & 3.61 & 1.04 & & \\
\hline & Between 45 - 54 Years & 2 & 4.40 & 0.57 & & \\
\hline \multirow{4}{*}{ Encouraging Intellectually } & Between 18 - 24 Years & 7 & 3.39 & 1.26 & \multirow{4}{*}{0.175} & \multirow{4}{*}{0.913} \\
\hline & Between 25 - 34 Years & 96 & 3.46 & 0.92 & & \\
\hline & Between 35 - 44 Years & 22 & 3.53 & 0.97 & & \\
\hline & Between 45 - 54 Years & 2 & 3.88 & 0.18 & & \\
\hline \multirow{4}{*}{ Paying Individual Attention } & Between 18 - 24 Years & 7 & 3.38 & 1.01 & \multirow{4}{*}{0.172} & \multirow{4}{*}{0.915} \\
\hline & Between 25 - 34 Years & 96 & 3.41 & 1.03 & & \\
\hline & Between 35 - 44 Years & 22 & 3.52 & 0.93 & & \\
\hline & Between 45 - 54 Years & 2 & 3.83 & 0.24 & & \\
\hline \multirow{4}{*}{ Having High Expectations for Success } & Between 18 - 24 Years & 7 & 3.38 & 0.95 & \multirow{4}{*}{0.387} & \multirow{4}{*}{0.762} \\
\hline & Between 25 - 34 Years & 96 & 3.72 & 0.83 & & \\
\hline & Between 35 - 44 Years & 22 & 3.71 & 0.63 & & \\
\hline & Between 45 - 54 Years & 2 & 3.67 & 0.00 & & \\
\hline
\end{tabular}

Table 12. Analysis of one-way variance between employees with different educational backgrounds in terms of transformational leadership and its sub-components.

\begin{tabular}{|c|c|c|c|c|c|c|}
\hline Sub-Components & Educational Background & $\mathbf{N}$ & Average & Standard Deviation & $\mathbf{F}$ & $\mathbf{p}$ \\
\hline \multirow{4}{*}{ Transformational Leadership } & High-school/2-year college & 22 & 3.83 & 0.81 & \multirow{4}{*}{0.174} & \multirow{4}{*}{0.914} \\
\hline & University & 92 & 3.48 & 0.85 & & \\
\hline & Master & 12 & 3.76 & 0.77 & & \\
\hline & $\mathrm{PhD}$ & 1 & 1.91 & & & \\
\hline \multirow{4}{*}{$\begin{array}{c}\text { Providing Vision-Inspiration and Being } \\
\text { a Proper Role Model }\end{array}$} & High-school/2-year college & 22 & 3.84 & 0.87 & \multirow{4}{*}{0.055} & \multirow{4}{*}{0.983} \\
\hline & University & 92 & 3.51 & 0.94 & & \\
\hline & Master & 12 & 3.81 & 0.79 & & \\
\hline & $\mathrm{PhD}$ & 1 & 1.88 & & & \\
\hline \multirow{4}{*}{$\begin{array}{c}\text { Providing the Acceptance of Group } \\
\text { Aims }\end{array}$} & High-school/2 year college & 22 & 3.87 & 0.86 & \multirow{4}{*}{0.578} & \multirow{4}{*}{0.630} \\
\hline & University & 92 & 3.48 & 0.95 & & \\
\hline & Master & 12 & 3.75 & 0.80 & & \\
\hline & $\mathrm{PhD}$ & 1 & 1.80 & & & \\
\hline \multirow{4}{*}{ Encouraging Intellectually } & High-school/2-year college & 22 & 3.85 & 0.91 & \multirow{4}{*}{0.175} & \multirow{4}{*}{0.913} \\
\hline & University & 92 & 3.36 & 0.92 & & \\
\hline & Master & 12 & 3.79 & 0.85 & & \\
\hline & $\mathrm{PhD}$ & 1 & 1.75 & & & \\
\hline \multirow{4}{*}{ Paying Individual Attention } & High-school/2-year college & 22 & 3.70 & 0.98 & \multirow{4}{*}{0.172} & \multirow{4}{*}{0.91} \\
\hline & University & 92 & 3.38 & 1.00 & & \\
\hline & Master & 12 & 3.53 & 0.99 & & \\
\hline & $\mathrm{PhD}$ & 1 & 1.67 & & & \\
\hline \multirow{4}{*}{ Having High Expectations for Success } & High-school/2-year college & 22 & 3.82 & 0.95 & \multirow{4}{*}{0.37} & \multirow{4}{*}{0.762} \\
\hline & University & 92 & 3.66 & 0.77 & & \\
\hline & Master & 12 & 3.83 & 0.73 & & \\
\hline & PhD & 1 & 2.67 & & & \\
\hline
\end{tabular}


Table 13. Analysis of one-way variance between employees in different age groups regarding organizational commitment and its sub-components.

\begin{tabular}{|c|c|c|c|c|c|c|}
\hline Sub-Components & Age & $\mathbf{N}$ & Average & Standard Deviation & $\mathbf{F}$ & $\mathbf{p}$ \\
\hline \multirow{4}{*}{ Organizational Commitment } & $18-24$ & 7 & 3.65 & 0.40 & \multirow{4}{*}{0.437} & \multirow{4}{*}{0.727} \\
\hline & $25-34$ & 96 & 3.57 & 0.62 & & \\
\hline & $35-44$ & 22 & 3.55 & 0.64 & & \\
\hline & $45-54$ & 2 & 4.04 & 0.18 & & \\
\hline \multirow{4}{*}{ Affective Commitment } & $18-24$ & 7 & 3.84 & 0.41 & \multirow{4}{*}{0.807} & \multirow{4}{*}{0.492} \\
\hline & $25-34$ & 96 & 3.57 & 0.75 & & \\
\hline & $35-44$ & 22 & 3.61 & 0.82 & & \\
\hline & $45-54$ & 2 & 4.25 & 0.35 & & \\
\hline \multirow{4}{*}{ Continuance Commitment } & $18-24$ & 7 & 3.59 & 0.50 & \multirow{4}{*}{0.382} & \multirow{4}{*}{0.766} \\
\hline & $25-34$ & 96 & 3.55 & 0.73 & & \\
\hline & $35-44$ & 22 & 3.44 & 0.94 & & \\
\hline & $45-54$ & 2 & 4.00 & 0.53 & & \\
\hline \multirow{4}{*}{ Normative Commitment } & $18-24$ & 7 & 3.54 & 0.47 & \multirow{4}{*}{0.116} & \multirow{4}{*}{0.950} \\
\hline & $25-34$ & 96 & 3.58 & 0.79 & & \\
\hline & $35-44$ & 22 & 3.61 & 0.65 & & \\
\hline & $45-54$ & 2 & 3.88 & 0.35 & & \\
\hline
\end{tabular}

Table 14. Analysis of one-way variance between employees with different educational backgrounds in terms of organizational commitment and its sub-components.

\begin{tabular}{|c|c|c|c|c|c|c|}
\hline Sub-Components & Educational Background & $\mathbf{N}$ & Average & Standard Deviation & $\mathbf{F}$ & $\mathbf{p}$ \\
\hline \multirow{4}{*}{ Organizational Commitment } & High-school/2-year college & 22 & 3.57 & 0.59 & \multirow{4}{*}{1.509} & \multirow{4}{*}{0.216} \\
\hline & University & 92 & 3.57 & 0.64 & & \\
\hline & Master & 12 & 3.71 & 0.31 & & \\
\hline & $\mathrm{PhD}$ & 1 & 2.38 & & & \\
\hline \multirow{4}{*}{ Affective Commitment } & High-school/2-year college & 22 & 3.60 & 0.80 & \multirow{4}{*}{2.794} & \multirow{4}{*}{0.163} \\
\hline & University & 92 & 3.62 & 0.75 & & \\
\hline & Master & 12 & 3.60 & 0.34 & & \\
\hline & $\mathrm{PhD}$ & 1 & 1.50 & & & \\
\hline \multirow{4}{*}{ Continuance Commitment } & High-school/2-year college & 22 & 3.58 & 0.64 & \multirow{4}{*}{0.962} & \multirow{4}{*}{0.413} \\
\hline & University & 92 & 3.50 & 0.82 & & \\
\hline & Master & 12 & 3.83 & 0.26 & & \\
\hline & $\mathrm{PhD}$ & 1 & 2.88 & & & \\
\hline \multirow{4}{*}{ Normative Commitment } & High-school/2-year college & 22 & 3.53 & 0.61 & \multirow{4}{*}{0.554} & \multirow{4}{*}{0.646} \\
\hline & University & 92 & 3.60 & 0.80 & & \\
\hline & Master & 12 & 3.70 & 0.52 & & \\
\hline & $\mathrm{PhD}$ & 1 & 2.75 & & & \\
\hline
\end{tabular}

${ }_{\mathrm{p}}^{*}<0.05, \stackrel{* *}{\mathrm{p}}<0.01$

organizational commitment, indicates the high perception regarding the transformational leadership attitudes and behaviors. "Having great expectations for success" has been found to have the highest average among all the components of transformational leadership. Considering this finding, leaders can be said to carry the features mostly of this component, among all the other components of transformational leadership.

Employees have been determined to have a high level of organizational commitment towards their institutions. 
Affective commitment, a sub-component of organizational component, has been found to have the highest average. Hence, it is possible to claim that employees adopt the aims of their institutions and they can make sacrifices by working harder in order to reach these aims.

The study has found a positive moderate relationship between the transformational leadership scale and the organizational commitment scale. Positive moderate and weak relations have been found between transformational leadership sub-components and organizational commitment scale sub-component. Hence, it is also possible to claim that leaders increase organizational commitment with their transformational leadership attitudes and behaviors.

No significant difference has been found in t test findings between two genders, and between existence and non-existence of management task in terms of "transformational leadership and its sub-components.” Based on these findings, it is possible to claim that leaders emerge as a result of having transformational leadership attitudes and behaviors equally towards all employees, and thus there is not any difference in perception.

There is not any difference found between genders in terms of organizational commitment and its sub-categories. However, a difference has emerged when it comes to existence of management task. Accordingly, participation level of employees with management task to “continuance commitment” sub-component has been found significantly lower than of employees without management task. Considering this fact, it will be prudent to claim that employees without management task think that if they leave the job their loss will be bigger than of employees with management task.

According to the results of analysis of one-way variance, there has not been any difference found between different age groups and different educational backgrounds in terms of transformational leadership scale and its cub-components. There has not been any difference found between different age groups and different educational backgrounds in terms of organizational commitment and its sub-components, either.

Managers shoulder important responsibilities to increase the organizational commitment of employees. Whether institutions can perform extraordinarily and become preeminent depends on its managers with leadership properties. Therefore, managers should boost the organizational commitment of employees by displaying transformational leadership attitudes and behaviors. Employees with high organizational commitment will always work harder than expected and they will always endeavor more in order to reach institution's aims. Leaders should act with this awareness. They also should determine the reasons for decrease in organizational commitment and take necessary measurements accordingly.

Under the ever-changing tumultuous environmental conditions of our day, studies on sense of transformational leadership, a type of leadership which focuses on changes, and on organizational commitment, one of the most important key factors for an institution's success, can be a guiding light for managers. In this sense, how different leadership models with sense of transformational leadership in different institutions can be subject to further researches.

\section{References}

[1] Deichmann, D. and Stam, D. (2015) Leveraging Transformational and Transactional Leadership to Cultivate the Generation of Organization-Focused Ideas. The Leadership Quarterly, 26, 204-219.

http://dx.doi.org/10.1016/j.leaqua.2014.10.004

[2] Genç, N. and Halis, M. (2006) Quality Leadership. Timaş Publications, İstanbul.

[3] Kazmi, S.A.Z and Naaranoja, M. (2015) 3rd International Conference on Leadership, Technology and Innovation Management Innovative Drives Get Fuel from Transformational Leadership’s Pied Pipers’ Effect for Effective Organizational Transformation. Procedia-Social and Behavioral Sciences, 181, 53-61.

[4] Dierendonck, D.V., Stam, D., Boersma, P., Windt, N. and Alkema, J. (2014) Same Difference? Exploring the Differential Mechanisms Linking Servant Leadership and Transformational Leadership to Follower Outcomes. The Leadership Quarterly, 25, 544-562

[5] Antonakis, J. and House, R.J. (2014) Instrumental Leadership: Measurement and Extension of TransformationalTransactional Leadership Theory. The Leadership Quarterly, 25, 746-771.

[6] Chun, C.H.V., Yuana, M.L., Chengb J.W. and Seifert, R. (2016) Linking Transformational Leadership and Core SelfEvaluation to Job Performance: The Mediating Role of Felt Accountability. North American Journal of Economics and Finance, 35, 234-246. http://dx.doi.org/10.1016/j.najef.2015.10.012

[7] Çelik, V. (2011) Educational Leadership. Pegem Academy, Ankara.

[8] Doci, E. and Hofmans, J. (2015) Task Complexity and Transformational Leadership: The Mediating Role of Leaders' 
State Core Self-Evaluations. The Leadership Quarterly, 26, 436-447.

[9] Celep, C. (2004) Transformational Leadership. Anı Publishing, Ankara.

[10] Kılınç, T. (2004) Charismatic Leadership: Description and Positive-Negative Aspects. www.merih.net/m2/lid/karizmatik.htm

[11] Paksoy, M. (2002) Human and Total Quality Management in the Work Environment. İstanbul University Publications No: 4356, Çantay Publishing, Istanbul.

[12] Birasnav, M. (2014) Knowledge Management and Organizational Performance in the Service Industry: The Role of Transformational Leadership Beyond the Effects of Transactional Leadership. Journal of Business Research, 67, 16221629. http://dx.doi.org/10.1016/j.jbusres.2013.09.006

[13] Kaygın, E. (2011) Understanding of Transformational Leadership in Entrepreneurship Process—A Study. Unpublished Ph.D Dissertation, Atatürk University, Institute of Social Sciences, Erzurum.

[14] Sarros, J.C. and Santora, J.C. (2014) The Transformational-Transactional Leadership Model in Practice. Leadership and Organization Development Journal, 22, 383-393. http://dx.doi.org/10.1108/01437730110410107

[15] Anderson, M.H. and Sun, P.Y.T. (2015) The Downside of Transformational Leadership When Encouraging Followers to Network. The Leadership Quarterly, 26, 790-801. http://dx.doi.org/10.1016/j.leaqua.2015.05.002

[16] Boylu, Y., Pelit, E. and Güçer, E. (2007) A Research on Organizational Commitment Levels of Academics. Journal of Financial, Political and Economical Comments, 44, 55-74.

[17] Gül, H. (2002) Comparison and Evaluation of Organizational Commitment Approaches. Ege Academic Overview, 2, 37-56. http://eab.ege.edu.tr/pdf/2_1/C2-S1-M4.pdf

[18] Song, J., Hong, M.K. and Kolb, J.A. (2009) The Effect of Learning Organization Culture on the Relationship between Interpersonal Trust and Organizational Commitment. Human Resource Development Quarterly, 20, 147-167. http://dx.doi.org/10.1002/hrdq.20013

[19] Korkmaz, O. and Erdoğan, E. (2014) Effect of Work Life Balance on Organizational Commitment and Employee Satisfaction. Ege Academic Overview, 14, 541-557.

[20] Sabuncuoğlu, E.T. (2007) Examination of the Relationship among Education, Organizational Commitment and Intention to Leave. Ege Academic Overview, 7, 613-628.

[21] Gürkan, Ç.T. (2006) Organizational Commitment: Influence of Organizational Climate on Organizational Commitment and Investigation of the Relationship between Organizational Climate and Organizational Climate. Master Thesis, Trakya University, Edirne.

[22] http://www.surveysystem.com/sscalc.htm

[23] Podsakoff, P.M, Mackanzie, S.B., Moorman, R.H. and Fetter, R. (1990). Transformational Leader Behaviours and Their Effects on Followers' Trust In Leader, Satisfaction, and Organizational Citizenship Behaviors. Leadership Quarterly, 1, 107-142. http://dx.doi.org/10.1016/1048-9843(90)90009-7

[24] Özdamar, K. (2002) Statistical Data Analysis with Software Packages 1. Kaan Publishing, Eskişehir.

\section{Submit or recommend next manuscript to SCIRP and we will provide best service for you:}

Accepting pre-submission inquiries through Email, Facebook, Linkedin, Twitter, etc

A wide selection of journals (inclusive of 9 subjects, more than 200 journals)

Providing a 24-hour high-quality service

User-friendly online submission system

Fair and swift peer-review system

Efficient typesetting and proofreading procedure

Display of the result of downloads and visits, as well as the number of cited articles

Maximum dissemination of your research work

Submit your manuscript at: http://papersubmission.scirp.org/ 